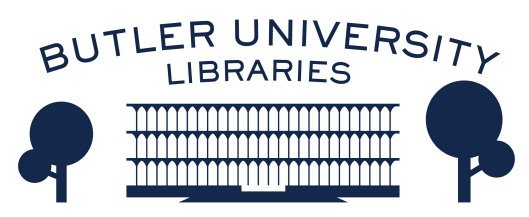

Journal of Hindu-Christian Studies

Volume 8

Article 5

January 1995

\title{
Sri Ramakrishna, Swami Vivekananda, and Hindu-Christian \\ Dialogue
}

Michael Stoeber

Follow this and additional works at: https://digitalcommons.butler.edu/jhcs

Part of the Religion Commons

\section{Recommended Citation}

Stoeber, Michael (1995) "Sri Ramakrishna, Swami Vivekananda, and Hindu-Christian Dialogue," Journal of Hindu-Christian Studies: Vol. 8, Article 5.

Available at: https://doi.org/10.7825/2164-6279.1110

The Journal of Hindu-Christian Studies is a publication of the Society for Hindu-Christian Studies. The digital version is made available by Digital Commons @ Butler University. For questions about the Journal or the Society, please contact cbauman@butler.edu. For more information about Digital Commons @ Butler University, please contact digitalscholarship@butler.edu. 


\title{
SRI RAMAKRISHNA, SWAMI VIVEKANANDA, AND HINDU-CHRISTIAN DIALOGUE*
}

\author{
Michael Stoeber \\ The Catholic University of America
}

IN THE LATE summer of 1993, representatives of the major religions of the world met in interfaith dialogue in Chicago, to celebrate the centenary of the 1893 World's Parliament of Religions. The 1893 Parliament was remarkable, both in its magnitude and its purpose: it brought together forty-one denominations and over four hundred men and women in a forum of mutual teaching and learning. ${ }^{1}$ That is to say, its formal purpose was reciprocal dialogue, something rather unusual for the 19 th century, when interfaith preoccupations of the time still normally focused on proselytism.

Swami Vivekananda attended the 1893 Parliament as a representative of Hindu Vedānta. Vivekananda was a most popular and noted speaker of the event, and his efforts during and following the 1893 Parliament contributed significantly to the introduction of Hindu beliefs and practices to the western world. ${ }^{2}$ And we see the influence today, in the many Ramakrishna Math and Mishna centres throughout the world. Indeed, Vivekananda carried interfaith dialogue far beyond the borders of India, emphasizing in this context an active social orientation and concern in his development of Hindu Vedānta.

His mentor and guru, Sri Ramakrishna, was himself an early advocate of dialogue between traditions. Sri Ramakrishna's interests in religion were truly eclectic: not only was he involved in practices of various Hindu traditions such as Tantra, Advaita, Yoga, and Vaiṣnavism, but he has also been noted for his interests in Buddhism, Sikhism, Jainism, Islam, and Christianity. Indeed, his experiences of elements of these different faiths led him to advocate a common divine Reality behind the many forms of religiousness, despite the many differences between traditions. He once commented, for example:
A lake has several ghāts [bathing places]. At one the Hindus take water in pitchers and call it "jal"; at another the Mussalmāns take water in leather bags and call it "pāni". At a third the Christians call it "water". Can we imagine that it is not "jal", but only "pāni" or "water"? How ridiculous! The substance is one under different names, and everyone is seeking the same substance; only climate, temperament, and name create differences. Let each man follow his own path. If he sincerely and ardently wishes to know God, peace be unto him! He will surely realize Him! ${ }^{3}$

Sri Ramakrishna's involvement in various faith traditions was primarily that of practice, and in this respect he was most involved in the spiritual experiences that these religions espouse. He was a profound mystic, which is to say most generally, he experienced in trance state union various spiritual realities behind this phenomenal existence, realizations that radically affected his perception of himself, others and the world. ${ }^{4}$ He possessed a tremendous vitality and charisma, and in his lifetime he attracted disciples, including Vivekananda. 
The interfaith leanings of his teacher no doubt inspired Vivekananda's interest and participation in the 1893 World's Parliament of Religions. For example, Ramakrishna's view of the universality of all authentic religions was echoed by Vivekananda in a hymn he recited in his response to the welcome at the Parliament:

As the different streams having their sources in different places all mingle their water in the sea, so, O Lord, the different paths which men take through different tendencies, various though they appear, crooked or straight, all lead to Thee. $^{5}$

In this paper I want to focus briefly on the contributions of Vivekananda and Ramakrishna to interfaith dialogue, as these pertain to religious experience - especially to their mysticism - and socio-moral practice. I will concentrate on their claims of a common core of religion, evaluating the possibility as well as the implications of such a perspective on Hindu-Christian dialogue, focusing specifically on that between Vedāntins and Roman Catholics.

What do I mean by interfaith dialogue? General but helpful distinctions have been proposed by the Pontifical Council for InterReligious Dialogue. The Council sees four interrelated levels of dialogue. Interreligious dialogue can exist at the routine level, in everyday community living between people of different faiths. This is the conversation of openness and camaraderie - of a kind of neighbourliness, I suppose - "the dialogue of life". Today, with our many multicultural communities, this kind of day-to-day interaction is becoming extremely important. But dialogue also happens in more theoretical contexts, in terms of "theological exchange" - in discussions of beliefs about the Divine, or the relation of the human to the Divine, or about morality, or spiritual anthropology, and so on. Related to the dialogue of theology is the dialogue of religious experience - of a sharing of prayer or meditation or contemplation - of an interfaith gathering in worship or spiritual ceremony or reflection. And finally, there is the "dialogue of action" - of social concerns and commitment, of coming together to improve living conditions or for the sake of the victims of poverty and social injustice. ${ }^{6}$

The dialogue of theology is perhaps the initial stumbling block in Vedāntin-Roman Catholic relations, given the many variations of dogma between the two traditions. There are obvious differences on various issues of theological belief. To name a few: the nature and status of Jesus; the role and importance of the Church; afterlife beliefs; the ideas of sin, grace, karma, and samsära; the role of sacraments and the clergy; and the nature and status of the Divine.

This last issue is quite central, and has been a subject over the years of some controversy. Is the Divine of the Vedāntins the same all-powerful, all-loving, allbenevolent Creator conceived by Roman Catholics? Indeed, when Catholic and Vedāntin theologians come together to dialogue about the Divine, are they speaking of the same thing?

To begin to think this issue out a bit, we should note first that for both Vedāntins and Catholics the Divine is not to be regarded as a phenomenal and distinctive "thing". Although some believers tend to objectify the Divine, to conceive and refer to Him or $\mathrm{Her}$ as if $\mathrm{He}$ or She were a major discrete phenomenon overseeing a creation of minor discrete phenomena, such reference is misleading and inaccurate. God is not an individual person. Indeed, the Divine, in the form of God or Brahman or Iśvara or Śakti, is not an object of this world, but rather absolutely transcends all objects of creation. In fact, this Divine is quite beyond all conceptualization and objectification. As Vivekananda said at the 1893 Parliament, the Absolute as absolute "cannot have any qualities. It cannot be an individual".

In theological language this view of the Divine is understood as apophatic - as consisting of negative conceptions. The Divine is most accurately depicted over and against everything It is not; "neti, neti - not 
this, not that". Most properly, this Divine cannot be described positively at all. It surpasses positive ascription altogether. It is beyond all moral reference or personal connotations. In Advaita Vedānta, this Divine is nirguna: "Brahman is without qualifiers (nirviśesa), without form (arūpa), without change, without parts, without end (advitiya or advaita)" 8 It is non-dual, without distinctive features and parts, and inactive or non-creative. Brahman is relationless, and hence beyond personal and moral reference. It is a Reality which cannot relate or communicate because it is not distinct from anything else - because it is not a personal Being.

This depiction of the Divine as inactive, impersonal, and surpassing moral reference leads to questions about the relationship of Brahman to the phenomenal world and its creator. As Krishna Sivaraman poses the problem:

The problematic of Vedanta which finds expression on almost every page of the Upanisads is really the problem of deity and deitas, concreteness and ultimacy, God and "the God beyond God", their relation and balance. ${ }^{9}$

In Vedānta this question comes to be answered in terms of a distinction between saguna and nirguna Brahman - Brahman with or without qualities. Describing the Advaitic position, Swami Nikhilananda says,

According to Non-dualistic Vedānta the personal God is one step lower than Brahman though $\mathrm{He}$ is the highest symbol or manifestation of Brahman in the relative world. ...Iśvara is, as it were, a corruption or deterioration of Brahman. ${ }^{10}$

Sankara and other Advaitins do indeed speak of a personal, creative Divine, but this Divine, like the rest of this phenomenal world, is a facet of avidya $\bar{a}$ (nescience). ${ }^{11}$ As Ramakrishna understands this view:

The jnānis, who adhere to Non-dualistic Vedānta, say that the acts of creation, preservation, and destruction, the universe itself and all its living beings, are the manifestations of Śakti, the Divine Power. If you reason it out, you will realise that all these are illusory as a dream. Brahman alone is the Reality, and all else is unreal. ${ }^{12}$

Although the created phenomenal realm, what Advaitins come to call $m \bar{a} y \bar{a}$, is significant on its own terms and from a practical standpoint, it is regarded as ultimately illusory and unreal, and not essentially connected and related to nirguna Brahman; and the human essence is regarded as identical to nirguna Brahman. That is to say, the only thing ultimately real about ourselves corresponds identically to Brahman, and so our distinctive, creative, personal, and moral aspects are finally regarded as illusory and unreal as well. Indeed, the goal is not a loving personal relationship with God and others, but rather a realization of identity of Self with this inactive and impersonal Divine, and release from this phenomenal world and individual existence. Even though a positive sociomoral stance is considered a correlative to the Advaitic liberating realization, the ideal is non-dual liberation.

Roman Catholics are uneasy about views suggesting the only thing ultimately real about people and the Divine is an inactive and impersonal non-dualism beyond moral reference. That is, they cannot accept perspectives that deny the importance of personal individuality and the ideal of personal fulfilment, as well as the supreme significance of moral activities such as love and compassion towards God and other human beings. The idea that the Divine in its highest form is a personal and moral Being who creates and loves human beings and this world, and that people are individual beings created in the personal and moral image of this Divine are basic suppositions for Catholics, and theists in general. As Karl Potter poses the problem:

What is difficult to comprehend from the standpoint of ordinary theism is that the Advaitin can say all this about God 
and yet view him as conditioned by ignorance. [Saguna] Brahman is the Supreme, the texts say, and yet in the same breath they affirm that $\mathrm{He}$ is not only not the Highest, His properties are unreal, false attributions of our ignorant super-impositions. ${ }^{13}$

So we see the initial resistance of Catholics to views which deny the ultimate reality of a personal Divine and the essential individual moral and personal nature of people.

But, in his eclectic, interfaith leanings, one of the more striking aspects proposed by Ramakrishna is that the Divine, more than nirguna Brahman, is both passive and active, impersonal and personal, beyond morality and moral. Ramakrishna says

\begin{abstract}
it is true that God reveals himself to his devotees in various forms. But it is also true that God is formless; $\mathrm{He}$ is the Indivisible Existence - Knowledge bliss Absolute. He has been described in the Vedas both as formless and as endowed with form. $\mathrm{He}$ is also described there both as attributeless and as endowed with attributes. ${ }^{14}$
\end{abstract}

In his mysticism, Ramakrishna claims to realize both non-dualistic and theistic types of experiences - both jada samādhi and cetana samādhi. ${ }^{15}$ Not only did he realize the static and impersonal identity with Brahman, but he also encountered a personal and active Divine in various forms, one which he affirmed to be just as real and significant as nirguna Brahman. About these different experiences, he says,

the Reality is one and the same; the difference is only in name. He who is Brahman is verily Ätman, and again, $\mathrm{He}$ is the Bhagavān. He is Brahman to the followers of the path of knowledge, Paramātman to the Yogis and Bhagavān to the lovers of God. ${ }^{16}$

How can the Divine be both Brahman and Bhagavān? Apparently Ramakrishna feels the Divine nature includes elements which correspond both to Advaitic impersonal unity and Bhakti theistic personalism. There is a personal God of this world, who creates and maintains it, who is involved in a relationship of love and compassion with people. But there is also a non-dualistic facet of this deity, the Divine in and behind the personal and active Source of $m \bar{a} y \bar{a}$, which corresponds to the apophatic or negative theology I spoke of above. Both passivity and activity, impersonalism and personalism are elements of this Divine. As Ramakrishna puts it:

When I think of the Supreme Being as inactive - neither creating nor preserving nor destroying - I call him Brahman or Purusha, the Impersonal God. When I think of him as active creating, preserving, and destroying - I call Him Śakti or Māyā or Prakriti, the personal God. But the distinction between them does not mean a difference. The Personal and the Impersonal are the same thing, like milk and its whiteness, the diamond and its lustre, the snake and its wriggling motion. It is impossible to conceive of one without the other. The Divine Mother and Brahman are one. ${ }^{17}$

So we have a distinction without a difference - two different modes of a singular Divine, "like milk and its whiteness, the diamond and its lustre, the snake and its wriggling motion".

Ramakrishna in his mysticism stresses the interfaith dialogue of religious experience. Although he does not attempt to account theoretically for these different facets of the Divine, he insists that in mystical experience one can encounter both impersonal and personal aspects of the divine nature, that both are legitimate and real, indeed that both are elements of one divine Reality. He adamantly maintains the validity of personal, theistic experiences despite his immersion in monistic, Advaitic unity. His view on this matter, I think, has significant implications for the interfaith dialogue of theology; for it provides a common basis from which Roman Catholics and Vedāntins can come together and talk constructively about the Divine. 
It is important to point out that the same kind of negative theology we find in the idea of nirguna Brahman is present in the Christian tradition, although it has not always been stressed. Some Christian mystics speak of the Trinity of the three Persons in unity, prior to activity and personal differentiation. This is the state of Divinity where God somehow is not active, creative, and personal. Meister Eckhart, for example, calls this apophatic Divine the Godhead - the dark unknowable chasm where God rests passively in Him or Herself, in non-dualistic unity, prior to differentiation and activity. We find similar ideas in the Pseudo-Dionysius, Jan Van Ruusbroec, and some other Christian mystics. Even St Bonaventure, for example, deduces from the idea of God as primary Being the fact that God must be Eternal, Simple, Actual, Perfect, and One, which is to say apophatically that God as pure Being is inactive, impersonal, and beyond moral reference. In Catholic theology, just as in Vedānta, we find speculation about elements of a non-dual Divine, that is to say, conceptions of the Divine as impersonal and inactive.

More importantly, all of these Christian thinkers, like Ramakrishna, insist also upon personal and active elements of the Divine, over and above the negative conceptions. This Divine is a living Being - indeed, a Trinity of Persons who can be experienced; She or $\mathrm{He}$ is real and most powerful and creative, and actively involved in creation. Although the Divine is not a person, She or $\mathrm{He}$ exudes personal and moral characteristics. She or $\mathrm{He}$ is creative and loving and compassionate; moreover, like Ramakrishna, Christian mystics claim we can experience these personal powers and energies directly, through devotional meditative techniques - through bhakti yoga.

So Ramakrishna's view of the different aspects of the Divine provides a basic framework for Hindu-Christian dialogue, and supports the claim that there is indeed a common Divine behind the various forms of religious faith. By emphasizing and legitimizing personal and active elements of the Divine, he opens the dialogue to theistic Christians. Moreover, the mysticism of Ramakrishna and Vivekananda also has significant implications for the dialogue of social action. Ramakrishna's view of a Divine who is both passive and active, impersonal and personal, non-dual and differentiated is also important in the interfaith dialogue of social action, for it helps to begin to reconcile isolating contemplative meditation with socio-moral aspirations.

Vivekananda says:

If you put God in your every movement, in your every conversation, in your form, in everything, the whole scene changes, and the world instead of appearing as one of woe and misery becomes a heaven. ${ }^{18}$

You must try to combine in your life immense idealism with immense practicalities. You must be prepared to go deep into meditation now and the next moment you must be ready to go and cultivate these fields. ${ }^{19}$

Vivekananda was deeply concerned with combining contemplative meditation with social activism. In the life of Ramakrishna we find the intimations of this reconciliation. The ideas of both an impersonal and personal Divine help us to harmonize the contemplative life with an active social orientation.

This happens when we understand both monistic and theistic realizations as transformative experiences in the human movement towards divinity. Vivekananda said at the 1893 Parliament: "To the Hindu... the whole world of religions is only a travelling, a coming up, of different men and women, through various conditions and circumstances to the same goal". ${ }^{20}$ Both passive monistic immersion in the impersonal Divine and active theistic union with the personal Divine can be thought to be essential elements of this movement to the goal. But to be able to fully integrate, 
live out, or exude the elements of these theistic, devotional experiences requires, according to some mystics, an immersion corresponding to Advaitic identity with Brahman. Monistic experiences of the impersonal and inactive Divine are here associated with the processes of completely letting go of one's ordinary egoistic "Iorientation" in the world; in order to become most properly a vehicle of divine expression in the world, one must undergo the monistic immersion in nirguna Brahman in the Hindu tradition or in Godhead in the Christian tradition respectively. For this submersion in the transcendent Source is a radical self-emptying process which opens one up, so to speak, to the active, personal, and moral energies of the Divine - to the possibility of becoming a living channel or medium of divine expression and creativity. I call this perspective "theo-monistic mysticism", and see it as an important development in the Hindu-Christian dialogues of theology and action. ${ }^{21}$

This theo-monistic dialogue of theology and social action is based in that of religious experience. A lucid contemporary example of such a grounding is illustrated in the life and writings of Henri Le Saux. He was a Benedictine monk deeply involved in such interreligious practice. In 1950, he along with Abbé Jules Moncharin established Saccidānanda ashram at Kulittalai, Tamil Nadu. In India he became a Christian sannyāsin (renunciate), a disciple of both Ramana Maharshi and Sri Gnanananda, taking the name Abhishiktananda, and studying the Upanishads. ${ }^{22}$ Echoing the feelings of Ramakrishna and Vivekananda, Henri Le Saux emphasizes both the impersonal and personal aspects of the Divine and the essential divinity of humankind. Also, he acknowledges the importance of uncovering this element in giving the Divine expression in the world. He saw the Advaitic non-dual experience of the impersonal and inactive Brahman as aptly voicing an experience crucial to one's spiritual transformation. He said:
The "death" implied in advaitic experience is essential in man's growing into himself. ${ }^{23}$

For Christian faith this void means a perfect readiness to receive everything from God, making no claim whatsoever either to be, or to be like this or like that. ${ }^{24}$

For Abhishiktananda, the Advaitic experience of nirguna Brahman opened up the possibilities of the highest experiences of Christian union with an active and personal God, leading to the expression of this Divine in everyday life.

This discovery of the ultimate recesses of the self is necessary if the Spirit is to complete his work in the created world. Man is a "microcosm", and only by opening up in man the foundation of his being can the Spirit transform and spiritualize the cosmos to its depths. ${ }^{25}$

Through an immersion in the transcendent Source, one is opened to the active, personal, and moral energies of the Divine; and in the process the mystic becomes a creative channel or medium of these spiritual energies, expressing them in the social realm.

Ramakrishna and Vivekananda would seem to exemplify to some degree this theomonistic movement, a spiritual transformation we find evidenced also in some traditional Christian mysticism as well as in that of Ramanuja and Aurobindo Ghose. ${ }^{26}$ Ramakrishna speaks of a Divine who is both active and passive, and personal and impersonal, and he stresses the experience of both aspects of the Divine in his mysticism, while Vivekananda advocates a spiritual transformation that attempts to relate together contemplative meditation and social activism. Both men illustrate, I think, in their own distinctive ways and in varying degrees, the effects of this transformation in their life and teachings. In these respects they contribute significantly to the HinduChristian interfaith dialogue of experience, and point the way towards integrating the 
dialogues of theology and social action with this experiential core of religion.

\section{Notes}

* A version of this paper was presented at the Gandhi Memorial Center, Bethesda, Maryland, 18 September 1993, in Celebration of Rashtriya Chetna Varsh, Commemorating the Centenary Year of Swami Vivekananda's Address to the 1893 Parliament of World's Religions in Chicago. The event was sponsored by the Embassy of India, Washington, D.C., the Indian Community, and the Gandhi Memorial Center. My thanks to two anonymous readers of the Hindu-Christian Studies Bulletin and to William Cenkner, for their helpful suggestions.

1. Egal Feldman, "American Ecumenicism: Chicago's World's Parliament of Religions of 1893", Journal of Church and State, 9,2 (1967), p. 183; and "General Information" bulletin of the Council for a Parliament of the World's Religions.

2. See Marie Louise Burke, Swami Vivekananda in the West: New Discoveries: His Prophetic Mission, Part I, third edition. Calcutta: Advaita Ashrama, 1983, pp. 85101; and Norman R. Adams, "Background of Some Hindu Influences in America - The Ramakrishna Movement", Ecumenical Studies, 9,2 (Spring 1972), p. 325-6.

3 The Gospel of Sri Ramakrishna, Swami Nikhilananda (tr.). N.Y.: RamakrishnaVivekananda Center, 1958, pp. 60-1.

4 For an interesting summary of the various kinds of visionary, ecstatic, tantric, and unitive religious experiences given in the biographies of Ramakrishna, see June McDaniel, The Madness of the Saints: Ecstatic Religion in Bengal. Chicago: The University of Chicago Press, 1989, especially pp. 92-103.

5. Swami Vivekananda, The Complete Works of Swami Vivekananda, Vol. 1, Mayavati Memorial Edition, 12th ed. Calcutta: Advaita Ashrama, 1965, p. 4.

6. Cardinals Francis Arinze and Josef Tomko, "Dialogue and Proclamation", Origins: CNS Documentary Service, 21,8, (July 4, 1991), p. 129.
7. Swami Vivekananda, The Complete Works of Swami Vivekananda, Vol. 1, p. 13.

8. Karl H. Potter, Advaita Vedānta up to Śamkara and His Pupils, Encyclopedia of Indian Philosophies, Vol. III. Delhi: Motilal Banarsidass, 1981, p. 74.

9. Krishna Sivaraman, "God-Language and the Language of Nothing", God, the Self and Nothingness: Reflections Eastern and Western. Robert E. Carter (Ed.), New York: Paragon House, 1990, p. 156. I discuss Sivaraman's view on this question in more detail in Theo-Monistic Mysticism: A HinduChristian Comparison. N.Y.: St. Martin's Press, pp. 66, and 76-8.

10. Swami Nikhilananda, Self-Knowledge of Sri Sankaracharya. Mylapore, Madras: Sri Ramakrishna Math, 1970, pp. 76-7.

11. Sengaku Mayeda discusses Sankara's treatment of this problem in his Upadeśasāhasrī, where Sankara gives an early theory of vivartaväva (false appearance) through the postulatation of an "unevolved Name-and-Form" that corresponds to avidyā. This "unevolved Name-and-Form" is "the supersensible seed of the world. ...On the one hand he [Sankara] stresses its essential difference from Brahman... . On the other hand he asserts that it evolves from Brahman" (p. 22). "Brahman, the cause of the universe, is real, while the world, the effect, is unreal" (p. 26). A Thousand Teachings: The Upadeśasāhasri of Śankara. Sengaku Mayeda, (tr. and ed.) Albany, N.Y.: State University of New York Press, 1992, especially pp. 18-26 and II, 1, 18-19.

12. The Gospel of Sri Ramakrishna, p. 193.

13. Potter, Advaita Vedanta up to Śamkara and His Pupils, p. 77.

14. The Gospel of Sri Ramakrishna, p. 241.

15. The Gospel of Sri Ramakrishna, pp.311-12.

16. The Gospel of Sri Ramakrishna, p. 192.

17. The Gospel of Sri Ramakrishna, p. 54.

18. Norman R. Adams, "Background Of Some Hindu Influences in America - The Ramakrishna Movement", p. 335.

19. Norman R. Adams, "Background of Some Hindu Influences in America - The Ramakrishna Movement", p. 337.

20. Swami Vivekananda, The Complete Works of Swami Vivekananda, Vol. 1, p. 18. 
21. I think the thought of Bede Griffiths, Wayne Teasdale, Louis Dupré, and Michael von Brück reflect and support this view in certain respects. I discuss various facets of theo-monistic mysticism in Theo-Monistic Mysticism: A Hindu-Christian Comparison.

22. Helen Ralston, Christian Ashrams: A New Religious Movement in Contemporary India. Lewiston, N.Y.: Edwin Mellen Press, 1987, pp.36,92. See also "Abhishiktananda: An Interview with Odette Baumer-Despeigne Conducted by Sr. Pascaline Coff, O.S.B.", Bulletin of Monastic Interreligious Dialogue, 51 (October 1994), pp. 17-24. In this interview Odette Baumer-Despeigne gives a very lucid and fascinating account of key events in Abhishiktananda's life and she highlights significant elements of his interreligious thought.

23. Abhishiktānanda, Saccidānanda, Delhi: I.S.P.C.K., 1974, p. 83

24. Abhishiktānanda, Saccidānanda, p. 107. My emphasis.

25. Abhishiktānanda, Saccidānanda, p. 87. My emphasis.

26. I develop the theo-monistic perspectives of Meister Eckhart, Jan Van Ruusbroec, Jacob Boehme, Ramanuja, Aurobindo, and Abhishikananda in Theo-Monistic Mysticism: A Hindu-Christian Comparison. 